\title{
The Development of Interactive Media Assisted by Macromedia Flash to Improve the Ability of Understanding the Fiction Story Information in Elementary School Students
}

\author{
Anggi Chairunnisa Siregar ${ }^{1}$, Abdurahman Adisaputera ${ }^{2}$, Anita Yus $^{3}$ \\ ${ }^{1}$ Postgraduate Program of Universitas Negeri Medan, Indonesia \\ ${ }^{2,3}$ Universitas Negeri Medan, Indonesia \\ anggisiregar325@gmail.com
}

\begin{abstract}
This study aims to: (1) Analyze the effectiveness level of interactive learning media assisted by Macromedia Flash on story text learning that will be developed at Public Elementary School 060856 Medan Perjuangan Subdistrict. (2) Analyze how the level of interactive learning media assisted by Macromedia Flash in story text learning that will be developed at Public Elementary School 060856 Medan Perjuangan Subdistrict. This study uses Borg \& Gall development research. Based on the analysis of learning media products assisted by Macromedia Flash from the experts, it was declared very effective and feasible to use with criteria of the validity of the material experts $85.42 \%$, the design expert $91.00 \%$, and the linguist $85.00 \%$. Based on the completeness data of student learning outcomes before using interactive learning media assisted by Macromedia Flash obtained an average score of 62 while after using a large scale completeness reached an average of 90 with a gain score of 0.74 into the high category. And the student questionnaire responses to the effectiveness of interactive learning media assisted by Macromedia Flash reached $90 \%$ of 30 students. Based on this data interactive learning media assisted by Macromedia Flash are said to be effectively used in learning with the assumption that students' understanding of story text is higher when using interactive learning media assisted by Macromedia Flash.
\end{abstract}

Keywords macromediaflash story text; students thinkingskills

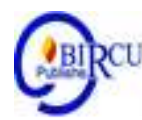

\section{Introduction}

Education is a conscious effort made by the family, community, and government through the activities of guidance, teaching, and training, which take place in school and outside of school to prepare students to play their roles appropriately in a variety of environments (Rohman, 2009: 9). Education makes humans try to develop the potential that exists within themselves to be able to deal with any changes that occur in life.

Advances in science and technology have influenced the use of teaching aids in schools and other educational institutions. For schools that are already advanced and capable, have used these tools as teaching aids, so learning becomes more effective and efficient. However, what needs to be considered is that all school equipment and supplies must be adapted to the demands of the curriculum, materials, methods, and level of students' ability to achieve learning objectives. Then the instructors are expected to be able to use these tools or equipment effectively and efficiently in classroom learning. 
Information technology and computers have developed rapidly nowadays. This technology has an extraordinary influence. One of the implications can be felt in the development of learning media that are now computer aided. In multimedia learning also has an important role in determining the quality of education, therefore teachers must use the methods and media used appropriately. Learning media is a messenger technology that can be used for learning purposes. Learning media is a physical means to deliver subjects. The word "media" comes from Latin, which is "medius" which literally means the middle, the introduction, or the intermediary of the two sides.

Learning media are needed by students in supporting their learning process in class because media is still the main source of learning for students. Learning media function as a tool in the learning process to achieve learning objectives. In facing the challenges of advancing science and technology, the role of the learning process must also be directed at the use of existing technology. Research conducted by Hosnan (2014) mentions the use of technology by children in Indonesia is still relatively low when compared to developed countries, such as Europe, Australia, and the United States. Therefore the demand to develop IT-based learning is needed today. The next few years the number of Indonesian children who have computers will increase. Computers in general will be connected to the internet that will be used for learning.

In accordance with the opinion of M I Jawid Nazir (2012: 820), in his research journal entitled, "Skill development in Multimedia Based Learning Environments in Higher Education: An Operational Model" states that: "Using multimedia in a teaching and learning environment can support students to become thinkers critically fast learners, can solve problems, are suitable for finding information, and can further motivate their learning process. Lack of learning design can lead to a low learning environment. "The media component in the learning process is a communication process that takes place in a system. Therefore learning media occupies an important position as one of the components of the learning system. One important element as one of the components and planning of learning is to determine the learning media that will be used in the learning process. It is intended that the understanding of the material and concepts can be clearly understood by students.

According to the observations of researchers at students of Public Elementary School 060856 Medan Perjuangan Subdistrict have difficulty understanding learning material due to the lack of potential of the teacher to develop media, which allows it to be used in learning so as to be able to add information to students. This researchers found in thematic learning in the learning of text stories, which in fact, the teacher only uses textbooks, posters, pictures as the only source for introducing story texts.

\section{Review of Literature}

\subsection{The Ability of Understanding the Story Text Information}

The ability of understanding the story text information according to Harjasusana and Damaianti in Rustono (2010: 15) is the understanding of sentences which includes the ability to use the theory of structural relationships between sentences. Knowledge of structural relationships is useful in the process of understanding sentences, because sentences are a series of interrelated words in specific ways. The process of understanding sentences is part of the reader in understanding the contents of the reading. Goodman in Slamet (2006: 185) explains that reading comprehension is a process of reconstructing messages contained in the text being read. The process of reconstructing messages is multi-layered, interactive, and the process of forming and testing hypotheses occurs ". Reconstructing a message is an attempt by the reader to find out the content in the reading that the writer is trying to convey. Rustono 
(2010: 16) suggests reading comprehension is the understanding obtained from reading activities. This activity involves the reader, the text, and the contents of the message conveyed by the author. Someone can be said to understand the reading if he has obtained information or messages conveyed by the author, both implied and explicit.

From the various definitions that have been mentioned, it can be concluded that the ability to understand reading text information is an activity or process to obtain information in the reading to understand the reading contents. After the conclusion of reading comprehension is known, it can also be concluded that the reading comprehension ability. The ability to understand reading is the ability of readers to get the information in the reading. With this ability the reader can use his knowledge to understand the contents of the reading. So that the reader can grasp the intent that the writer intends to convey, either implicitly or explicitly.

\subsection{The Nature of Contextual Learning}

Berns and Erickson (2001: 2) explain "Contextual teaching and learning is a conception of teaching and learning that helps teachers relate subject matter content to real world situations; and motivates students to make connections between knowledge and its applications to their lives as family members, citizens, and workers; and engage in the hard work that learning requires ". So, contextual learning is an approach to learning that makes students more active in learning activities and helps students to be able to connect the knowledge gained in the classroom with the context in accordance with real life. The concept of learning that helps teachers to link teaching material with the real world situation of the students, can encourage students to make connections between the knowledge learned and its application in the lives of students as family members and the community (Sardiman, 2014: 222). Furthermore Johnson (2007) states Contextual Teaching and Learning is a learning system based on the philosophy that students are able to absorb lessons if they capture meaning in the academic material they receive, and they capture meaning in school assignments if they can relate new information with the knowledge and experience they

already have before. Contextual learning is a learning concept that helps teacher's link material taught with real-world situations of students and encourage students to make connections between the knowledge they have and their application in their daily lives, involving seven main components of learning effective, namely: constructivism, Questioning, Inquiry, learning community, modeling, reflection, and Authentic Assessment (Kadir, 2013).

\subsection{Learning Media}

Musfiqon (2012: 28) revealed that learning media can be used more fully as an intermediary between teachers and students in understanding learning material to be more effective and efficient. Asra (2009: 5) argues that the word media in "learning media" literally means an intermediary or introduction, while the word learning is interpreted as a condition created to make someone do something learning activities. Learning media emphasizes the position of the media as a vehicle for channeling messages or learning information to condition a person learning.

Learning media can represent what teachers are less able to pronounce through words. The abstractness of the material can be concretized with the presence of learning media. Arsyad (2011: 115) argues that the use of teaching media in the teaching and learning process can arouse new desires and interests, arouse motivation and stimulation of learning activities and even bring psychological influences on students. The use of instructional media at the stage of teaching orientation will greatly assist the effectiveness of the learning process and delivery of content at the time. In addition to arousing student motivation and interest, 
teaching media can also help students increase understanding, present data attractively, facilitate data interpretation and condense information. Learning media have different characteristics from one another. Hernawan (2007: 22-34) explains the characteristics of learning media according to type, viz. a) Visual media is media that can only be seen. b) Audio media is media that can only be heard. c) Audio visual media is a combination of audio visual or commonly called listening media.

\subsection{Interactive Learning Media of Macromedia Flash}

In planning and implementing learning activities, each teacher can prepare and function all the elements that support the smooth learning process so that it can run effectively and efficiently. As one of the elements in supporting learning, teachers are required to be able to know and design the use of instructional media and can take on the functions and uses of these media. Understanding interactive with two-way communication or more than the components of communication. The component of communication in interactive multimedia (computer-based) is the relationship between humans (as users / users of products) and computers (software / applications / products in certain file formats, usually on CD). Thus the product / CD / application that is expected to have a two-way / reciprocal relationship between software / applications with their users. Interactiveity in multimedia is given the following restrictions: (1) the user is involved in interacting with the application program, (2) the interactive information application is intended so that the user can get only the desired information without having to devour everything. Based on this understanding, it can be concluded that interactive media is a multimedia display designed by desaigner so that the appearance fulfills the function of informing the message of having interactivity with its user.

\section{Research Methods}

This type of research is Research and Development with the design of learning development models by Dick and Carey. The steps include: 1) Conducting preliminary research; 2) Making software design; 3) Collection of materials; 4) Developing macromedia flash; 5) Product reviews and trials; and 6) Test the effectiveness of the product. This research was conducted in class IV of Public Elementary School 060856 Medan Perjuangan Subdistrict. Data collection instruments in this development are assessment instruments to assess the products that have been developed. In addition, questionnaires were also given to students, this questionnaire was used to obtain data on the attractiveness and accuracy of the material provided to students which included aspects of media appearance and media content. Besides the data collection in this study is a test of learning outcomes, the test is used to assess the ability of students after using contextual based interactive multimedia. Before the test is used, first test is tested for validity, reliability, level of difficulty, and the different power of the questions.

\section{Discussion}

\subsection{Materials Expert Validation of Learning}

Materials expert validation of learning towards the development of interactive learning media assisted by Macromedia Flash and the ability to understand story text information in IV grade students of Public Elementary School 060856 Medan Perjuangan Subdistrict. The assessment is conducted to obtain information that will be used to improve the quality of Macromedia Flash-assisted interactive learning media and the ability of understanding story text information. The results of the validation take the form of an assessment score on aspects 
of the social studies learning material that includes the appropriateness of the content, the appropriateness of the presentation, comments and suggestions for improvement and conclusions.

From the results of the overall assessment of learning material experts stated that the level of achievement score about the feasibility of the content and the feasibility of the presentation was 85.42 where the range was at the level of achieving the score 85-100 categorized as "Very Good". The results of the assessment of information understanding activities material in the text of the story developed received several comments including: (a) each material displayed KD, (b) the material illustrations are displayed visually video, (c) cases outside the region are not optimal, (d) glossary in The material does not yet exist, (e) the involvement of students is still in the form of exercises, and the suggestions are to improve in accordance with the results of the discussion.

\subsection{Linguists Expert Validation of Learning}

Linguists expert validation to the learning language towards the development of Macromedia Flash-assisted interactive learning media and the ability of understanding the story text information in fourth grade students of Public Elementary School 060856 Medan Perjuangan Subdistrict, which included aspects of language standardization, accuracy of language use, language suitability, presentation of target characteristics, clarity of language in instructions, clarity of material exposure, and appropriateness of evaluation with material.

The conclusions from the results of the assessment by the learning design expert covering the aspects of the attractiveness of physical appearance, the accuracy of the use of the design, the suitability of the format, the presentation of the characteristics of the target, the clarity of media instructions, the clarity of material exposure, and the suitability of the evaluation with the overall material. , 00 where the range is at the level of achieving a score of 85-100 is categorized as "Very Good". The results of the assessment of the learning design on the development of interactive learning media received several comments including: (a) the media must be made in accordance with the learning strategies / methods / models, (b) each meeting must be displayed KI, KD, indicators and learning objectives, (c) the learning design includes the initial, core, and closing activities, (d) at the end of the interactive multimedia a glossary must be made, and the suggestion is to revise the multimedia in accordance with the comments. The conclusion of the assessment, comments and suggestions by learning design experts that interactive learning media assisted by Macromedia Flash is worth testing in the field with revisions.

\subsection{Design Expert Validation of Learning Media}

Design expert validation of learning media on the development of Macromedia Flashassisted interactive learning media and the ability of understanding the story text information in fourth grade students of Public Elementary School 060856 Medan Perjuangan Subdistrict assessed from all aspects contained in the Macromedia Flash-assisted interactive learning media validation sheet for media design experts.

The conclusion from the media design experts that the results of the assessment by instructional media design experts that include aspects of media display design, media programming design, and overall media content design can be concluded that the level of achievement of the score of the media design expert is 91.00 where the range is at the level of achieving the score $85-100$ are categorized as "Very Good".

The results of the assessment of media design experts on the design of instructional media on the development of interactive learning media assisted by Macromedia Flash received several comments including: (a) the design used was good, the menu display was also in accordance with the level of students who used it. (b) please improve the animation 
because the animation used is not interesting (c) use a real and appropriate image. (d) the media layout is not interesting enough to make it according to students' needs. and the suggestion is that all data from the results of the media expert review be used as a basis for revision in order to perfect the learning media content before being tested on students as users of development products. The conclusion of the assessment, comments and suggestions by learning design experts that Macromedia Flash-assisted interactive learning media deserves to be tested in the field with revisions, and the results of the assessment of media design experts on instructional media design on the development of Macromedia Flash-assisted interactive learning media received several comments including: (a) it is necessary to add a user guide, (b) a summary is placed on each sub-theme. The conclusion of the assessment, comments and suggestions by design experts of learning that interactive learning media assisted by Macromedia Flash is worth testing in the field with revisions.

\subsection{Individual Trial}

Individual trial conducted in class IVa of Public Elementary School 060856 Medan Perjuangan subdistrict consisting of 3 students that 1 student with high achievement, 1 student with moderate achievement, and 1 student with low achievement. Analysis of individual trial data covering aspects of media display and content of Macromedia Flashassisted interactive learning media on the comprehension of story text information material as a whole reached $81.67 \%$ included in the "Very Good" category. The results of the assessment and response to interactive learning media assisted by Macromedia Flash on individual trials conducted by 3 students, shows that the product developed is suitable for use and there is a suggestion for improving grammar in the media by students in individual trials on the development of interactive learning media products assisted by Macromedia Flash, so that the development activities continued in small group trials with revisions

\subsection{Small Group Trial}

A small group trial was also carried out in class IVa Public Elementary School 060856 Medan Perjuangan subdistrict, which consisted of 6 students, that 2 students with high achievement, 2 students with moderate achievement students, and 2 students with low achievement. From the small group trials it can be concluded the results of the assessment and small group trial responses to the development of Macromedia Flash-assisted interactive learning media obtained overall was $90.42 \%$. Thus the response to the dominant small group trial gives an excellent response to the quality of Macromedia Flash-assisted interactive learning media. The students' classical learning completeness can be calculated with the following formula:

$$
\begin{aligned}
& \text { PKK }=\frac{\text { Total of students complete }}{\text { Total of research subjects }} \cdot x 100 \% \\
& \text { PKK }=\frac{4}{6} x 100 \%=67 \%
\end{aligned}
$$

Based on the data above there are $67 \%$ of students who have reached $\mathrm{KB} \geq 70 \%$. After students' completeness in the learning process individually and classically is analyzed, the results of the pre-test and post-test are calculated with a gain score.

Based on the gain score test results obtained 0.50 then the gain score on a small scale test of 6 people is classified as moderate. For a clearer picture of the results of pre-test and post-test students can be seen in the following figure: 


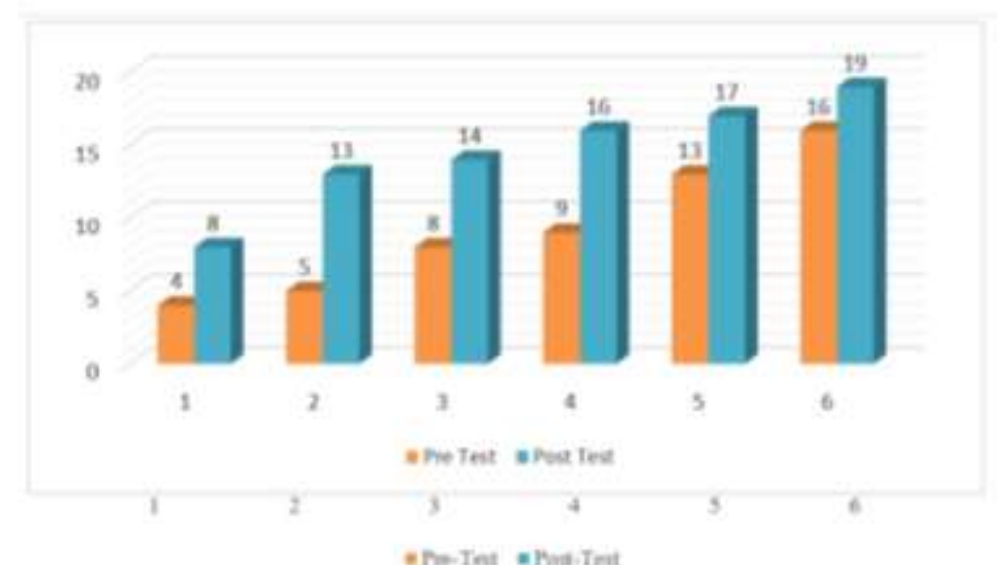

Figure 1. Diagram of Pre-Test and Post-Test Small Scale Test Students

\subsection{Analysis of Mastery Learning Large Scale Test Students} formula:

The students' classical learning completeness can be calculated with the following

$$
\begin{aligned}
\text { PKK } & =\frac{\text { Total of students complete }}{\text { Total of research subjects }} \cdot x 100 \% \\
\text { PKK } & =\frac{27}{30} \times 100 \% \\
\text { PKK } & =90 \%
\end{aligned}
$$

Based on the complete classical learning completeness data above there are $90 \%$ of students who have reached $\mathrm{KB} \mathrm{KB} 70 \%$. After completeness of students in learning individually and classically analyzed, the results of pre-test and post-test are calculated by the gain score. To see an increase in the value and effectiveness of the media developed between before and after using a nominal gain score formula. Based on the gain score the result obtained is 0.74 , the gain score on the large scale test is quite high. For more details about the results of pre-test and post-test large-scale test can be seen in the following figure:

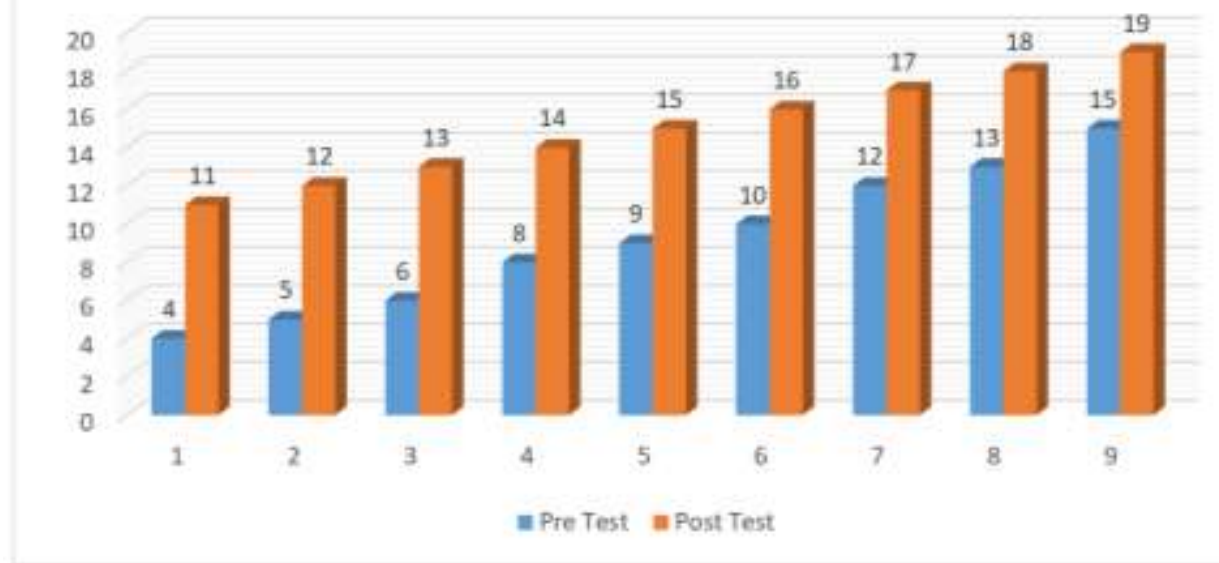

Figure 2. Diagram of Pre-Test and Post-Test Large Scale Student Test

\subsection{Discussion}

To find out the feasibility of Macromedia Flash-assisted interactive learning media, a validity test was conducted by material experts, design experts, and media experts. Where each expert provides an assessment on each discussion contained in the sheet, the learning 
media validation is in the form of a quantitative descriptive assessment questionnaire that is disclosed in the distributor score and assessment scale category.

The validity that is carried out at the validity test stage is theoretical validity, that is, validity with experts and competent in their fields based on theoretical and logical considerations. There are 3 parts of Macromedia Flash-assisted interactive learning media that will be validated namely material, language and media. Interactive learning media developed need to be validated to obtain eligibility so that it is suitable for use in learning. In the validation stage the researcher conducts an assessment with discussion languages by showing the initial design of interactive learning media, which in this case uses Macromedia Flash, to learning language experts, material experts and instructional media experts. In addition, researchers also provide validation sheets to the validator in order to get the theoretical validation results. The experts give an assessment in accordance with the validator sheet provided by researchers.

Based on the validation of material experts it is known that the validation assessment is $84.09 \%$ with valid criteria but there is still an improvement from the material experts. Material experts suggest fixing simple words so they are understood by students. After revised the percentage to $92,11 \%$ valid with very valid criteria. After discussing with material experts, Macromedia Flash-assisted interactive learning media is based on validator input and suggestions. Based on the validation of learning design experts based on aspects of content, presentation, linguistic appearance and content got an assessment of $78.57 \%$ in both categories. Validators suggest that the colors on the media used are more varied, and the writing size is enlarged so that all students can see clearly. After being revised, it is suitable for students to use.

Furthermore, the media feasibility test was tested on individual students with the results of a percentage of $81.67 \%$ and on a small scale trial of 6 people obtained a percentage of $90.42 \%$ with a very good category and very feasible to use. In line with Trianingrum and Airlanda (2017) said that the use of interactive multimedia is very feasible to use in learning at Public Elementary School 060856.

Based on the results of the study showed the feasibility of interactive learning media assisted by Macromedia Flash media aspects of 4.00, material aspects of 3.23, and language aspects of 4.11. In a limited trial the results of the student questionnaire showed eligibility of 4.34 and a teacher questionnaire of 4.70 . While the results of student questionnaires in extensive trials showed the feasibility of 4.44. Based on the results of a series of due diligence processes, Macromedia Flash-assisted interactive learning media developed is suitable for use in understanding text story information. This is in line with research from Handayani (2018) saying that the feasibility of macromedia flash is influenced by the results of student and expert response questionnaires, if the results of student responses increase and the average results of experts are in the high category then the development of media is suitable for use in learning

Based on the assessment given by the validator and also the assessment given by students to the Macromedia Flash-assisted interactive learning media that was developed as well as suggestions and input provided by the experts, Macromedia Flash-assisted interactive learning media developed was said to be valid and appropriate for use in learning.

\section{Conclusion}

Based on the development of interactive learning media assisted by Macromedia Flash in IV grade of Public Elementary School 060856, Medan Perjuangan Subdistrict and discussion of research results that have been discussed previously, then some conclusions can 
be drawn including: 1) The content feasibility and the presentation feasibility on media products including the criteria of "very good" based on the results of the material experts trial with a percentage of $85.42 \%$; 2) The test results of learning language experts are in very good criteria $(91.00 \%) ; 3$,$) The test results of learning design language experts are in the sufficient$ criteria $(85.00 \%)$; 4) Individual trial results are in very good criteria $(81.67 \%)$; 5) The results of small group trials are in very good criteria $(90.42 \%)$; 6) Large group trial results are in good criteria (73.2\%). Also based on the results of the study it can also be concluded that also the development of interactive learning media assisted by Macromedia Flash can improve student learning outcomes.

\section{References}

Arsyad, A. (2011). Media Pembelajaran. Jakarta: Raja Grafindo Persada.

Asra, S. (2009). Metode Pembelajaran. Bandung: Wacana Prima.

Erickson \& Bern. (2001). Contextual Teaching and Learning. Economy, 2(1), 22-35.

Johnson, E. B. (2007). Contextual Teaching and Learning; Menjadikan Kegiatan Belajar Mengajar Mengasyikan dan Bermakna. Bandung: Mizan Learning Center (MLC).

Kadir, A. (2013). Konsep Pembelajaran Kontekstual di Sekolah. Dinamika Ilmu, 13(3), 17-38

Musfiqon. (2012). Pengembangan Media Belajar dan Sumber Belajar. Jakarta: Prestasi Pustakakarya.

Rusman, 2013. Belajar dan Pembelajaran Berbasis Komputer. Jakarta: Rajawali Pers.

Rustono, W.S. 2010. Pengaruh Metode Pembelajaran Membaca dan Tingkat Kecerdasan Terhadap Kemampuan Pemahaman Bacaan. Jurnal Saung Guru. Vol. 1. No.2.

Sardiman, A.M. (2014). Interaksi dan Motivasi Belajar Mengajar. Jakarta: Rajawali Pers. 